\title{
Correlations of Dietary Crude Protein and Gross Energy on Blood Glucose and Urea, Milk Urea and Lactose Concentrations in Lactating Ewes
}

\author{
Ali Gholi Ramin ${ }^{1}$, Ali Aghazadeh², Touraj Karamian ${ }^{1}$, Sina Ramin ${ }^{3}$ \\ ${ }^{1}$ Veterinary College, ${ }^{2}$ Agricultural College, Urmia University, Iran \\ ${ }^{3}$ Medical Sciences of Tabriz University, Tabriz, Iran
}

Received June 16, 2009

Accepted March 8, 2010

\begin{abstract}
Concentrations of serum glucose (SG) and urea (SU), milk lactose (ML) and urea (MU) and their relationships to dietary gross energy (GE) and crude protein (CP) were studied in 16 lactating ewes in Urmia, Iran. Ewes were aged 3 to 5 years and were bred in a closed pen. They were fed alfalfa hay, pasture grass, concentrate and corn silage. Each lactating ewe was nursing a single lamb. Five $\mathrm{ml}$ of blood from v. jugularis, $50 \mathrm{ml}$ milk and $200 \mathrm{~g}$ feed mixture were collected at 15 day intervals up to 135 days (9 samples). Serum glucose and urea concentrations were evaluated using a spectrophotometer, milk lactose in Polarimeter, gross energy by calculation method and crude protein by Kjeldahl methods. The mean values for dietary GE, CP, SG, SU, MU

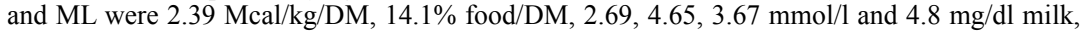
respectively. Significant differences $(P<0.01)$ were found for serum and milk indicators during the milking periods among the sampling times. Serum urea and milk urea irregularly increased while serum glucose and milk lactose irregularly decreased. Positive correlations were found $(P<0.05)$ between SU/MU $(\mathrm{r}=0.45), \mathrm{MU} / \mathrm{GE}(\mathrm{r}=0.75), \mathrm{MU} / \mathrm{CP}(\mathrm{r}=0.70)$ and SU/CP $(\mathrm{r}=0.97)$. Negative correlations $(P<0.05)$ were found between MU/SG $(r=-0.17)$, SU/ML $(r=-0.20)$ and MU/ML $(\mathrm{r}=-0.24)$. Based on results, it is concluded that urea, glucose and lactose would be appropriate variables in the prediction of crude protein and gross energy concentration of diet in lactating ewes.
\end{abstract}

$C P, G E$, ewe, correlations, equations

Diet plays an important role in providing gross energy and crude protein for growth, production and reproduction of animals. Two of the final products of carbohydrates and proteins in ruminants are glucose and urea. Meanwhile, serum glucose (SG) and protein are considered the initial component of milk. Therefore, there should be a relationship among diet, blood and milk compositions.

The values recommended for $\mathrm{CP}$ and $\mathrm{GE}$ in diet based on physical activities, physiological and reproduction performances in ewes are $2.4 \mathrm{Mcal} / \mathrm{kg} / \mathrm{DM}$ and $13 \%$ to $15 \%$ food/DM, respectively (NRC 1984). Furthermore, the values for SG and serum urea (SU), milk urea (MU) and milk lactose (ML) are1.9-3.1 mmol/1 (Radostits et al. 2000), 3.15-10.4 mmol/1 (Ramos et al. 1994), 2.5-6.7 mmol/1 and 4.8 milk dry matter \% (Gfrorer and Koch 1985), respectively. Factors affecting these indicators include the type of diet (Roseler et al. 1993; Cannas et al. 1998), protein and the ratio of energy to dietary protein (Bed et al. 1997), housing systems (Casamassima et al. 2001), estrus cycle (Knight et al. 1999), stage of lactation (Flock et al. 2001), pregnancy and parturition (Pulina et al. 1996).

Reports show that MU slightly increases when dietary GE is decreased (Cannas et al. 1998). In one study ML increased when the energy to protein ratio in diet increased (Bed et al. 1997). Ewes reared outdoor showed low SG and SU concentrations compared to the indoor reared animals (Casamassima et al. 2001). Bed et al. (1997) reported that ML decreased during the lactation period and Casamassima et al. (2001) mentioned it was high in the middle of lactation. One study reported that evening and morning MU differed

Address for correspondence:

Ali Gholi Ramin

College of Veterinary Medicine, Urmia University

P.O. Box 1177, Urmia, Iran
Fax: +441 2777099

E-mail: aliramin75@yahoo.com

http://www.vfu.cz/acta-vet/actavet.htm 
in goat milk but not in ewe milk (Bed et al. 1997) and others recorded monthly changes in SU concentration (Miettinen and Huthanen 1989; Tadich et al. 1994).

Correlations among diet, blood and milk indicators were recorded: SU/MU (Rois et al. 2002, Roseler et al. 1993), MU/CP (Cannas et al. 1998) and ML/SG (Bed et al. 1997) were positively correlated, while MU negatively correlated with GE (Cannas et al. 1998). No correlation was observed among MU/ML, MU/SG, CP/ML and GE/ML.

Milk and blood analyses have been used in some studies as an indicator of the dietary GE and CP status in sheep (Bed et al. 1997). In order to complete those findings, determination of the changes in diet, blood and milk indicators during the lactation period seems to be necessary. Understanding probable correlations among indicators is necessary in order to estimate the CP and GE in diet by measuring the SU and MU in ewes. The aim of this study was to determine the concentrations of SG, SU, ML and MU and calculate their relationships to dietary GE and $\mathrm{CP}$ in lactating ewes.

\section{Materials and Methods}

Sixteen lactating ewes from 3 to 5 years of age were randomly selected from the Urmia University flock. They were all in healthy condition and nursing a single lamb. The ewes were ear tagged and placed with the others in the flock. They were kept in a closed pen and fed three times per day by alfalfa hay in the morning, concentrate and corn silage at noon and pasture grass in the evening. The selected ewes had had normal lambing, and udder inflammation or mastitis were not observed during the experiment. Lambs of these ewes all survived with the appropriate growth rate. The experiment was carried out from mid winter to spring.

Five $\mathrm{ml}$ of blood from $\mathrm{v}$. jugularis was taken from ewes to obtain serum for measuring of serum glucose and serum urea concentrations. Fifty $\mathrm{ml}$ of milk were collected from each ewe, $40 \mathrm{ml}$ to evaluate the milk lactose (ML) and $10 \mathrm{ml}$ for milk urea (MU) concentrations. Two hundred grams of feed including 50 grams of alfalfa hay, grass pasture, concentrate and corn silage based on their nutritional program (fed ad libitum) were mixed and selected to estimate the amount of dietary GE and CP. Overall, the ewes were sampled 9 times during the experiment. Time of sampling was between 13:00 and 15:00 h. Blood and feedstuff samples were kept in a cool area and then tested early in the next morning.

Serum glucose and urea concentrations were analyzed by spectrophotometer (Auto-Analyzer, RA-1000, UK) using commercial glucose (Zeist-Chimi, IR) and urea (Pars Azmun, IR) kits. Milk lactose was evaluated by Polarimeter method (B+S, UK). Milk urea was measured by separation of the milk serum and then was run as SU. Crude protein of diet was measured by Kjeldahl method and GE of diet by calculation of the carbohydrate (CHO), moist, $\mathrm{CP}$, ash, ether extract (EE) and crude fibre (CF) according to the following formula:

$\mathrm{CHO} \%=100-($ Moist $\%+\mathrm{CP} \%+\mathrm{Ash} \%+\mathrm{EE} \%+\mathrm{CF} \%)$

$\mathrm{GE}(\mathrm{Cal} / 100 \mathrm{gm}$ diet $)=\mathrm{CP} \% \times 4+\mathrm{EE} \% \times 9+\mathrm{CHO} \% \times 4$

The SPSS $_{13}$ statistical program was used to analyse the data. The case summaries were applied to determine the mean, standard deviation and error of diet, blood and milk indicators. The repeated measure ANOVA (Wilks Lambda) was used to compare the means of indicators in the lactating period ( 9 times). Pearson correlation was applied to find the relationships between indicators. Regression analysis was carried out to determine the appropriate equations for the GE and CP in diet using blood and milk indicators.

\section{Results}

The mean and standard error of the mean (SEM) for dietary GE and CP intakes during 135 days lactation were $2.39 \pm 0.13 \mathrm{Mcal} / \mathrm{kg} / \mathrm{DM}$ and $14.1 \pm 1.05 \%$, respectively. The lowest and highest GE (1.74 and $2.77 \mathrm{Mcal} / \mathrm{kg} / \mathrm{DM})$ and $\mathrm{CP}(10.9 \%$ and $18 \%)$ were observed on days 45,15 and 75,30 , respectively.

The concentrations of SG and SU during the 135 lactating days are shown in Figs 1 and 2. The mean and SEM for SG and SU were $2.69 \pm 0.06$ and $16.5 \pm 0.5 \mathrm{mmol} / \mathrm{l}$, respectively. The highest and lowest concentrations for SG (3.8 and $1.95 \mathrm{mmol} / \mathrm{l})$ and SU (23.45 and $9.97 \mathrm{mmol} / \mathrm{l})$ were observed on 15,30 and 75,15 days of lactation, respectively. SG decreased up to 75 days of lactation and then increased up to 120 days after lactation. SU constantly increased up to 75 days of lactation and then varied up to the end of study. Mean comparison of SG and SU (Wilks Lambda) showed significant differences $(P<0.01)$ during 135 days of lactation (Table 1).

The mean and SEM for MU and ML during the study were $13 \pm 0.45 \mathrm{mmol} / \mathrm{l}$ and 


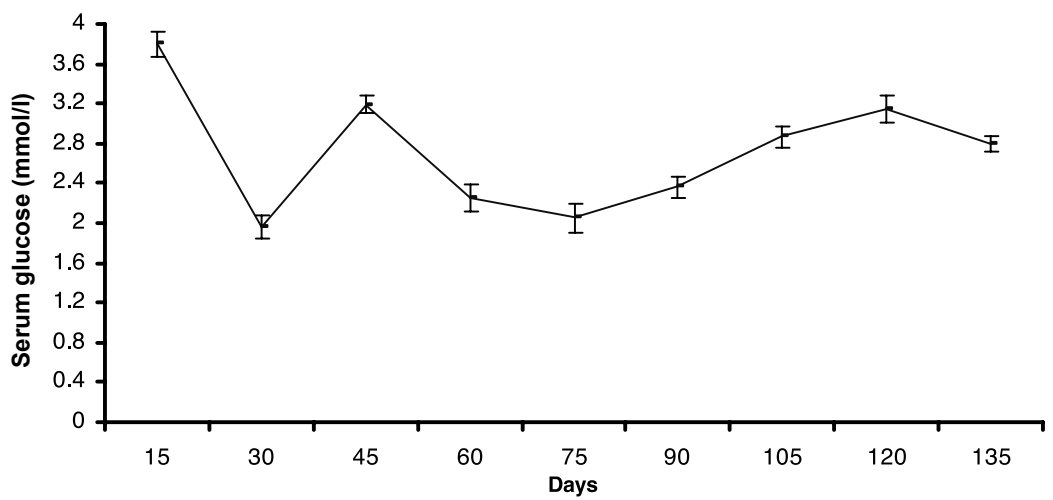

Fig. 1. Mean \pm SE of serum glucose concentration at 15 -day intervals up to 135 days of lactation $(n=16)$

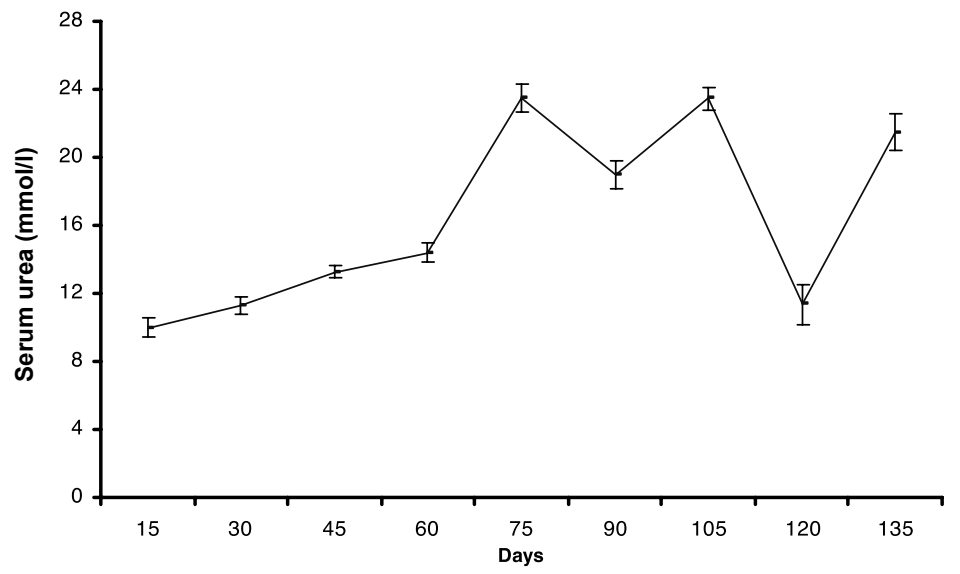

Fig. 2. Mean \pm SE of serum urea concentration at 15 -day intervals up to 135 days of lactation $(n=16)$

$4.8 \pm 0.1$ milk dry matter $\%$, respectively. Mean MU concentration increased inconstantly from 6.1 to $17.7 \mathrm{mmol} / \mathrm{l}$ within 135 days of lactation (Fig. 3). Mean ML was high (5.9 milk dry matter \%) at the time of study and then inconstantly decreased (4 milk dry matter \%) up to 105 days of lactation (Fig. 4). Wilks Lambda test showed significant differences $(P<0.001)$ in MU and ML concentrations during the sampling time (Table 1).

Significance of correlation coefficients among diet, serum and milk indicators were

Table 1. Results of Wilks Lambda on the serum glucose and urea, milk lactose and urea concentrations during the 135 days of lactation in ewes $(\mathrm{df}=8)$

\begin{tabular}{|c|c|c|c|}
\hline Indicators & Sum of square & Mean square & F-values \\
\hline Serum glucose & 12780.8 & 1597.6 & $22.1 * * *$ \\
\hline Serum urea & 30480.3 & 3810.1 & $52.1 * * *$ \\
\hline Milk urea & 10011.8 & 1251.5 & $11.5 * * *$ \\
\hline Milk lactose & 19.2 & 2.7 & $4.9 * *$ \\
\hline
\end{tabular}

found between SU/MU, SU/ CP, MU/ML $(P<0.01)$, SU/ $\mathrm{ML}, \mathrm{MU} / \mathrm{GE}$ and $\mathrm{MU} / \mathrm{CP}$ $(P<0.05)$. The correlations were also found between SG/ $\mathrm{SU}, \mathrm{SG} / \mathrm{ML}$ and $\mathrm{ML} / \mathrm{GE}$ at the level of $P<0.1>0.05$ (Table 2). According to the Tables 3 and 4, the regression equations for the prediction 


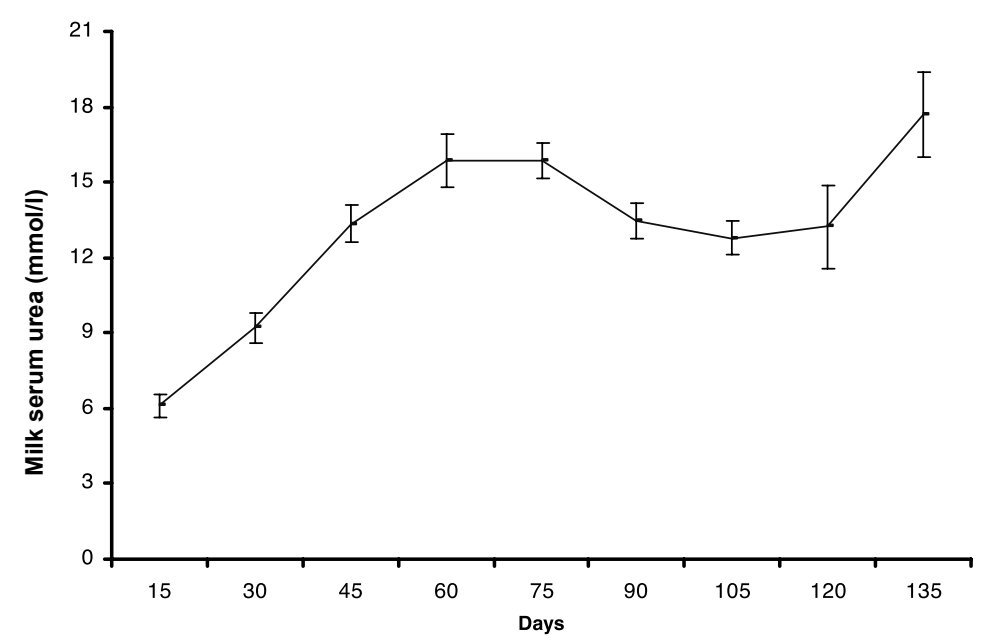

Fig. 3. Mean \pm SE of milk serum urea concentration at 15 -day intervals up to 135 days of lactation $(n=16)$

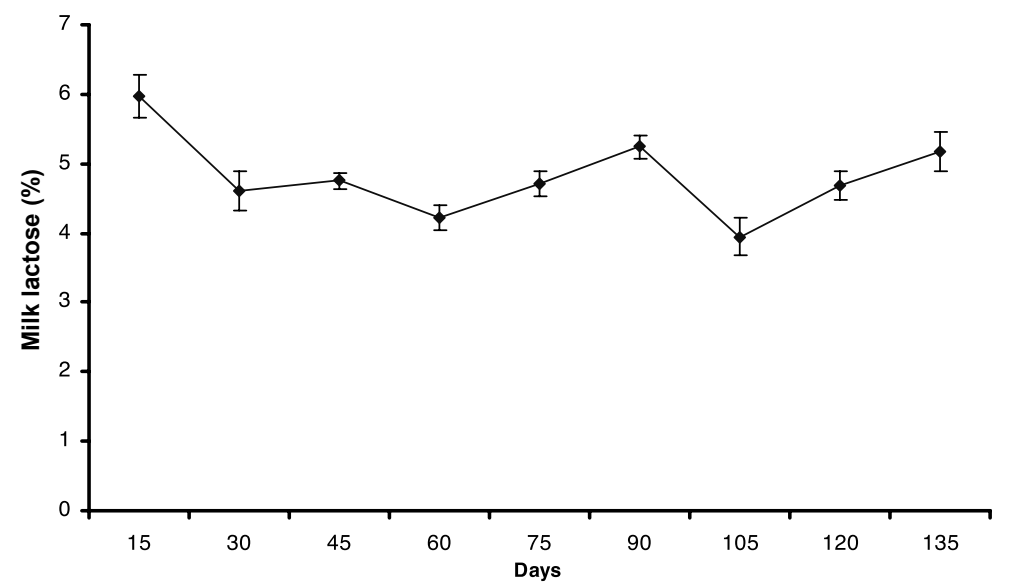

Fig. 4. Mean $\pm \mathrm{SE}$ of milk lactose concentration at 15-day intervals up to 135 days of lactation $(\mathrm{n}=16)$

of $\mathrm{CP}$ and GE in diet using $\mathrm{SG}$ and $\mathrm{SU}, \mathrm{MU}$ and $\mathrm{ML}$ with the $\mathrm{R}^{2}$ for protein and energy intake explain 0.71 and 0.42 of the variables, respectively, are as follows:

$$
\begin{aligned}
& \mathrm{CP}=7.68-[(0.034 \pm 0.01) \mathrm{SG}]+[(0.14 \pm 0.01) \mathrm{SU}]+[(0.35 \pm 0.16) \mathrm{ML}] \\
& \mathrm{GE}=2.3-[(0.09 \pm 0.03) \mathrm{ML}]+[(0.013 \pm 0.002) \mathrm{MU}]
\end{aligned}
$$

\section{Discussion}

Gross energy recommended for lactating ewes is $2.4 \mathrm{Mcal} / \mathrm{kg} / \mathrm{DM}$ (NRC 1984) which supports the findings of this study. The range was from 1.74 to $2.77 \mathrm{Mcal} / \mathrm{kg} / \mathrm{DM}$. Dietary GE could be stabled in a hand-operated and closed experiment but this study was an observational one and the values were varied based on the amount of diet available and their proportion and composition, and finally, the rate of grass growth during the 135 days. According to the findings of Roseler et al. (1993), dietary GE is influenced by days of sampling, dietary proportion and method of nutrient analysis. In this study sampling times 
Table 2. Correlations among diet, serum and milk inditarors during the 135 days of lactation in ewes

\begin{tabular}{|l|c|c|c|c|c|}
\hline Indicator & Serum urea & Milk urea & Milk lactose & Gross energy & Crude protein \\
\hline Serum glucose & $-0.1{ }^{\dagger}$ & $-0.17^{*}$ & $0.16 \dagger$ & -0.01 & -0.31 \\
\hline Serum urea & & $0.45^{* *}$ & $-0.20^{*}$ & 0.38 & $0.97^{* *}$ \\
\hline Milk urea & & & $-0.24^{* *}$ & $0.75^{*}$ & $0.70^{*}$ \\
\hline Milk lactose & & & & $-0.64 \dagger$ & -0.07 \\
\hline Gross energy & & & & & 0.31 \\
\hline
\end{tabular}

$* *=P<0.01, *=P<0.05, \dagger=P<0.1>0.05$

Table 3. Regression correlations between dietary crude protein with serum and milk indicators

\begin{tabular}{|l|c|c|c|c|c|}
\hline \multirow{2}{*}{ Indicator } & \multicolumn{2}{|c|}{ Unstandard coefficient } & Standard coefficient & \multirow{2}{*}{ t-value } & $P$ \\
\cline { 2 - 6 } & $\mathrm{B}$ & $\mathrm{SE}$ & $\mathrm{B}$ & 7.53 & 0.01 \\
\hline Constant & 7.68 & 1.02 & 0.16 & 2.83 & 0.01 \\
\hline Serum glucose & 0.034 & 0.012 & 0.801 & 14.73 & 0.01 \\
\hline Serum urea & 0.142 & 0.010 & 0.122 & 2.23 & 0.03 \\
\hline Milk lactose & 0.351 & 0.157 & & & \\
\hline
\end{tabular}

Dependent variable $=$ Dietary crude protein, $\mathrm{R}^{2}=0.71, P<0.01, \mathrm{SE}=1.02$, Standard error of the estimate $=0.54$

Table 4. Regression correlations between dietary GE and milk indicators

\begin{tabular}{|l|c|c|c|c|c|}
\hline \multirow{2}{*}{ Indicator } & \multicolumn{2}{|c|}{ Unstandard coefficient } & Standard coefficient & \multirow{2}{*}{ t-value } & $P$ \\
\cline { 2 - 6 } & $\mathrm{B}$ & $\mathrm{SE}$ & $\mathrm{B}$ & 13.9 & 0.01 \\
\hline Constant & 2.3 & 0.17 & & 3.14 & 0.02 \\
\hline Milk lactose & 0.09 & 0.03 & 0.24 & 7.0 & 0.01 \\
\hline Milk urea & 0.01 & 0.002 & 0.54 & & \\
\hline
\end{tabular}

Dependent variable $=$ gross energy, $\mathrm{R}^{2}=0.42, P<0.01, \mathrm{SE}=0.17$, Standard error of the estimate $=0.32$

were fixed at 13:00 to 15:00 h, food was sampled according to its consumption and laboratory analyses were carried out by an advanced auto-analyzer and current laboratory methods. Therefore, the reason for variation in dietary GE could be related to the differences in the quality and quantity of concentrates and corn silage. Dietary GE influences the milk yield and its composition in lactating ewes. High dietary GE increases milk yield and its fat, and decreases milk protein (Bocquier and Caja 1998). The effects of high and low dietary GE on milk yield and its composition were demonstrated in other study (Agus and Bocquier 1995) but without a conclusion regarding MU and ML.

Mean dietary CP recommended for lactating ewes is $13 \%$ (NRC 1984). In this study, it was $14 \%$ and showed enough $\mathrm{CP}$ in alfalfa and grass hay that have a high $\mathrm{CP}$ content. The role of $\mathrm{CP}$ in ruminant life, milk yield and composition is the same as mentioned for dietary GE (Bocquier and Caja 1998). However, the effect of low CP on growth, production and reproduction is more critical than high $\mathrm{CP}$ in diet.

The range for glucose concentration cited by Radostits et al. (2000) was 1.9-3.1 mmol/1 and in this study it was $2.69(1.95-3.8) \mathrm{mmol} / \mathrm{l}$. The $95 \%$ confidence interval was 2.58 $2.74 \mathrm{mmol} / \mathrm{l}$ that was in agreement with values recommended by Radostits et al. (2000) for ewes. The lowest (1.95) and highest (3.8) values in our study were slightly higher than values given by Radostits et al. (2000) but the mean value (2.69) was exactly in the recommended range. This showed that the nutritional program in this herd and for experimental ewes was in normal condition and no dietary deficiency would be expected. Serum glucose participates in the secretion of milk and approximately $85 \%$ of milk lactose is synthesized from SG (Bed et al. 1997). Although the ewes were in the lactating stage, 
SG was in the recommended range. Variations in SG during the lactation period in our study are the same as recorded for pregnant ewes by Firat and Ozpinar (2002).

Mean SU and MU concentrations in this study were consistent with the results of Ramin et al. (2005), Gfrorer and Koch (1985) but SU was lower than reported by Zadnik et al. (1993). Urea resulting from protein catabolism appears in blood and milk content. Concentration of urea in milk of up to $5 \mathrm{mmol} / \mathrm{l}$ indicates that ewes have had appropriate $\mathrm{CP}$ in their diet. It has been shown that the increase in MU starts from the second month of lactation (Tadich et al. 1994), as we also observed. It has been shown that milk urea is affected by dietary GE and CP (Cannas et al. 1998), starvation (Miettinen and Juvonen 1990), milk yield (Tadich et al. 1994) and evening or morning milk yield (Bed et al. 1997). The effect of MU on the quality of milk is open to investigation. In terms of economy and hygiene, low urea has more benefits for milk than high urea, but no report has considered the side effects of high urea on milk. Some reports (Bed et al. 1997) suggested MU and $\mathrm{ML}$ as indicators to determine the SG and SU concentrations and their relationships to dietary GE and CP.

The mean ML concentration for ewes was consistent with other finding (Bed et al. 1997). The lowest value was found at 105 days of lactation. Variation in ML is controversial. Milk lactose has been reported to decrease by up to $13 \%$ during lactation (Bed et al. 1997). Some reports mentioned high ML concentration during the first lactation (Wholt et al. 1981). Other factors influencing ML could be milk yield, milk protein and the ratio of energy to protein, animal species and mastitis (Burriel 1997). In this study ML declined gradually up to the end of study. The presence of significant differences in blood and milk indicators during the lactation period (Table 2) means that these indicators differed in terms of the sampling times. It means that blood components vary during lactation and are influenced by physiological activities, such as body metabolism, milk yield and dietary intake, digestion and absorption. Variations between these indicators were all within the normal range.

The presence of significant correlations among indicators showed the close relationships among the diet, blood and milk compositions. Of them, urea was more reliable than others, thus it may serve as an indirect indicator of the energy or protein estimation in blood and diet. A few correlations have been reported between SU/MU (Ramin et al. 2005), SG/SU (Firat and Ozpinar 1996) and ML/SG (Bed et al. 1997) as found in this study too. The result for correlation between CP and MU was supported by Cannas et al. (1998) but it was the converse of the result between MU and GE. This discrepancy is probably due to the administration of high $\mathrm{CP}$ in diet, low $\mathrm{CHO}$ and high rumen microflorea activity as mentioned by Rutter and Manns (1986). The correlations in this study and other reports may also account for the reliability of ML as well as MU in determination of dietary CP and GE status.

The equations presented here to estimate the dietary GE and CP necessary in the ewes ration using $\mathrm{ML}, \mathrm{MU}, \mathrm{SG}$ and $\mathrm{SU}$ with the squared term for $\mathrm{CP}(0.71)$ and GE diet $(0.42)$ have not been reported before. Thus, another experiment is necessary to prove the validity of equations in ewes. The absence of SG in the estimation of dietary GE could be related to glycogenesis pathway in the ruminants via free fatty acids and low SG concentration in ruminants is comparable to those in horse and human.

It is concluded that the mean blood and milk indicators measured here were at the recommended concentrations for lactating ewes. The presence of significant differences between the indicators at different sampling times reflects differences in the ewes' dietary ingredients. Significant correlations among the indicators and the presence of regression equations for the estimation of dietary $\mathrm{CP}$ and GE in lactating ewes indicates the reliability and importance of urea, glucose and lactose in predicting of $\mathrm{CP}$ and $\mathrm{GE}$ in diet. 


\section{References}

Agus A, Boucquier F 1995: Contribution of body reserves to milk production in under nutrition ewes. IV Symposium International Sur la nutrition des Herbivores, Clermont, September 1995. Annales de Zootech 44: 320

Bed S, Nikodemusz E, Gunndel K, Nagy Z 1997: Relation of plasma concentration of urea, glucose and total protein to milk levels of urea, lactose and protein of grazing ewes during lactation. Arch Tierz Dummerstorf 40: $265-275$

Bocquier F, Caja G 1998: Effects of nutrition on ewes' milk quality, Comparative FAO network on sheep and goats, Nutrition sub-network, 3-5 Sept., Grignon, France

Burriel AR 1997: Dynamics of intra-mammary infection in the sheep caused by coagulase-negative Staphylococci and its influence on udder tissue and milk composition. Vet Rec 140: 419-423

Cannas A, Pres A, Mancuso R, Vodrel B, Nudda A 1998: Effect of dietary energy and protein concentrations on the concentration of milk urea nitrogen in dairy ewes. J Dairy Sci 81: 499-508

Casamassima D, Sevi A, Patazzo M, Ramassiato R, Colella GE, Belitti A 2001: Effects of two different housing systems on behavior, physiology and milk yield of Comisana ewes. Dipartimento di Scienze Animali 41: 151-161

Firat A, Ozpinar, A 2002: Metabolic profile of pre-pregnancy, Pregnancy and early lactation in multiple lambing Sakiz ewes. 1. Changes in Plasma glucose, 3-hydroxybutyrate and cortisol levels. Ann Nutr Metab 46: 57-61

Flock M, Baumgratner M, Winter P, Ringdorfer F, Baumgratner W 2001: Factors influencing the content of urea in the milk of ewes. Berl Munch Tierarztl Wochenschr 114: 297-304

Gfrorer F, Koch G 1985: Determination of the urea content of milk in general practice. Tieraztl Prax 13: 559-563

Knight TW, Gosling LS, Dick HA 1999: Effects of hogget oestrus and the lambing and milking of hoggets on the subsequent milk composition and yields of 2 year old Dorset ewes, New Zealand. J Agric Res 38:197-204

Miettinen H, Huhtanen P 1989: The concentrations of blood metabolites and the relations between blood parameters, fatty acid composition of milk and estimated ME-balance in dairy cows given grass silage $a d$ libitum with five different carbohydrate supplements. Acta Agric Scand 39: 319-330

Miettinen PVA, Juvonen RO 1990: Diurnal variations of serum and milk urea levels in dairy cows. Acta Agric Scand 40: 289-296

NRC 1984. Nutrients requirements of sheep. Nationat Research Council, USA, pp: 48-49

Pulina G, Beneini R, Rassue SPG 1996: Relation between birth weights of lamb on milk production in ewes. Sto Arstvo 50: 199-203

Radostits OM, Gay CC, Blood DC, Hinchcliff KW 2000: Veterinary Medicine, $9^{\text {th }}$ Ed., Harcout Publishers Ltd, London, pp: 1417-1420

Ramin AG, Asri S, Majdani R 2005: Correlations among serum glucose, betahydroxybutyrate and urea concentrations in non-pregnant ewes. Small Rum Res 57: 265-269

Ramos JJ, Verde MT, Marca MC, Fernandez A 1994: Clinical chemical values and variation in Rosa Argora ewes and lambs. Small Rum Res 20: 133-139

Rois C, Marin M, Murraso A, Rudolph W 2002: Relationship between urea levels in blood and milk in dairy goats from the Chilean central area, XX11 World Buiatrics congress, 18-23 August, Hannoner, Germany, p. 630

Roseer DK, Ferguson JD, Sniffen CJ, Herrema J 1993: Dietary protein degradability effect on plasma and milk urea nitrogen and milk nonprotein nitrogen in Holstein cows. J Dairy Sci 76: 525-529

Rutter JA, Manns D 1989: Changes in metabolic and reproductive characteristics associated with lactation and glucose infusion in the postpartum ewe. J Anim Sci 63: 538-545

Tadich N, Wittwer F, Gallo C, Jorquera M 1994: Effecto de un programa de salud en ovinus sobre la condition corporal y los valores sanquines de-B-hidroxibutirato, hematocrite y urea. Arch Med 26: 43-50

Wohlt J, Kleyn D, Vande G, Selfridge D 1981: Effect of stage of lactation, age of ewe, sibling status and sex of gross and minor constituents of Dorset ewe milk. J Dairy Sci 64: 2175-2184

Zadnik T, Pengov A, Mijovic A, Lipuzic E, Pogacnik M 1993: Somatic call count and ewe milk composition. Prvi-Slovenski Veterinarski Kongres, pp: 18-22 
